\title{
Immune activation and antitumor response of ar-turmerone on P388D1 lymphoblast cell implanted tumors
}

\author{
DONGHEE KIM ${ }^{1}$, YONGJOON SUH ${ }^{2}$, HYUNSOOK LEE ${ }^{3}$ and YONGKYU LEE ${ }^{3}$ \\ ${ }^{1}$ Research and Development Center, Daewoo Pharm. Co., Ltd., Saha-gu, Busan 604-030; \\ ${ }^{2}$ Laboratory of Molecular Biochemistry, Hanyang University, Seongdong-Ku, Seoul 133-791; \\ ${ }^{3}$ Department of Food and Nutrition, Dongseo University, Busan 617-716, Republic of Korea
}

Received September 13, 2012; Accepted October 17, 2012

DOI: $10.3892 /$ ijmm.2012.1196

\begin{abstract}
Aromatic turmerone (ar-turmerone) has been reported to have a cytotoxic effect on L-1210 and HL-60 cells. In the present study, we investigated the anticancer responses and immune activities in implanted tumor cells. Our study found that ar-turmerone inhibited the increase in the number of white blood cells, which normally increase by the injection of lymphoblast cells, or P388D1, and ar-turmerone increased lymphocyte percentage compared to the control. Tumor inhibition rate in the ar-turmerone-treated group was $11.79 \%$, and the apoptosis indexes of the control, ar-turmerone and Glivec groups were $4.22 \pm 1.02,5.45 \pm 1.46$ and $10.01 \pm 2.01$, respectively, in which only the Glivec-treated group showed a significance. The positive rates of Bcl-2 and Bax proteins which were treated by ar-turmerone did not show marked differences compared to the control group, but the Bax protein in the Glivec-treated group increased compared to the control group. The density of caspase-1, -3, -6, -9, Bcl-2, Bax, p21 and p53 mRNA in the control, ar-turmerone and Glivec groups did not change considerably, but the Bax mRNA of the Glivec-treated group increased compared to the control group. The ar-turmerone-treated group increased T-lymphocyte and B-lymphocyte proliferation activities compared to the control group, which was more significant in T-lymphocyte than in B-lymphocyte proliferation activity. The interleukin-2 (IL2) production activity of the ar-turmerone group increased compared to the control group. These findings suggest that ar-turmerone does not have a chemotherapeutic effect on tumor incidence, but it has a repressive effect on P388D1 lymphocytic leukemia. Furthermore, this protective effect of ar-turmerone from P388D1 lymphocytic leukemia resulted from the increased activity of tumor immunogenicity through increased T-lymphokine production and increased percentage of lymphocytes.
\end{abstract}

Correspondence to: Dr Yongkyu Lee, Department of Food and Nutrition, Dongseo University, San 69-1, Jurae-Dong, Sasang-Gu, Busan 617-716, Republic of Korea

E-mail: lyk@dongseo.ac.kr

Key words: apoptosis, aromatic turmerone, implanted tumor cell, caspase, tumor, interleukin-2, immunogenicity

\section{Introduction}

Aromatic turmerone (ar-turmerone) is a major compound present in turmeric volatile oil from Curcuma longa L. Curcumin has been known to be a major component of this plant, but ar-turmerone, which is a sesquiterpene, is also an effective component of Curcuma longa L. $(1,2)$. It possesses insecticidal (3), antivenomous (4) and moderate antineoplastic activities $(5,6)$. It was reported that ar-turmerone had a cytotoxic effect on L-1210 and HL-60 cells (7). Our previous study based on this finding highlighted ar-turmerone-mediated apoptotic protein activation on the growth of human histiocytic lymphoma U937 cells (8). Our study revealed ar-turmerone-mediated apoptosis according to the following features.

Stereotypical features of a cell undergoing apoptosis include cell shrinkage, blebbing, phosphatidylserine externalization, DNA fragmentation and nuclear condensation (9). Early in the apoptotic process, mitochondria release cytochrome $c$, which enters cytosol and forms a complex with Apaf-1 and a pro-form of caspase-9 (10). This complex induces the activation of other caspases, which are responsible, either directly or indirectly, for the cleavage of several intracellular proteins that characteristically lyse during apoptosis $(11,12)$. The P53 protein is also involved in the process by responding to DNA damage and inducing apoptosis, which is likely to be a crucial aspect of the role of p53 as a tumor suppressor (13-15). Non-repaired cells might be eliminated during apoptosis through the induction of Bax and the repression of Bcl-2 factors $(16,17)$. Bax, pro-apoptotic protein, induces the release of cytochrome $c$ and the activation of caspase, resulting in apoptosis. Apoptosis can be blocked by antiapoptotic proteins such as Bcl-2 and Bcl-xL (18). The induction of apoptosis in tumor cells has been shown to be the generalized rule for numerous cancer therapies in conjunction with other anticancer mechanisms. In addition to this generalized rule, some cytotoxic drugs showed immunepotentiating effects in the tumor microenvironments, which suggests that antitumor responses were associated with the immune system (19-22).

Despite some in vitro evidence of the antitumor effects of ar-turmerone, its in vivo effects have rarely been reported. This study was designed to investigate the antitumor activity and immunity of ar-turmerone in implanted tumors of mouse 
lymphoblast cells, or P388D1. Understanding the relationship between immunogenicity and antitumor response in vivo may allow for ar-turmerone's clinical application.

\section{Materials and methods}

Isolation and identification of ar-turmerone. Powdered Curcuma longa (400 g) was extracted twice with hexane to remove curcumin and its derivatives. The extract (13.27 g) was then evaporated under vacuum. The residue was dissolved in $\mathrm{MeOH}$. For the partial purification of ar-turmerone, the filtered solution was fractionated with a Buchi MPLC system (Buchi pump C-605, column $1.5 \times 23 \mathrm{~cm}$, fraction collector Buchi C-660) using LiChroprep C-18 (40-63 $\mu \mathrm{m}$; Merck) as an adsorbent. The pooled fraction was extracted with ethyl acetate and water. The ethyl acetate layer was evaporated under reduced pressure, after which the residue was dissolved in $\mathrm{MeOH}$. To achieve higher purity, the $\mathrm{MeOH}$ solution was injected into a semi-preparative liquid chromatography apparatus (Young Lin Instruments Co., Ltd., Korea) equipped with a Gemini C18 column (10x250 mm; Phenomenex Co. Ltd.). $\mathrm{MeOH}$ solution $(70 \%)$ was maintained at a flow rate of $5 \mathrm{ml} / \mathrm{min}$. The pooled fractions were evaporated under vacuum and extracted with ethyl acetate and water. The ethyl acetate layer was evaporated under reduced pressure. A viscous oil (131.3 mg) was subsequently generated, identified as ar-turmerone by GC-Mass analysis and by comparing with the NIST library data (23).

$G C$-MS analysis. The viscous oil was analyzed by the GC-Mass electron impact ionization (EI) method on Agilent model $6890 \mathrm{GC}$ interfaced to a 5973 mass selective detector. HP-5MS capillary columns (30 mx0.25 mmx0.25 $\mu \mathrm{m}$ film thickness) were used for GC. The oven temperature was maintained at $60^{\circ} \mathrm{C}$ for $6 \mathrm{~min}$ then programmed to $240^{\circ} \mathrm{C}$ at the rate of $5^{\circ} \mathrm{C} / \mathrm{min}$. The carrier gas was helium, at a flow rate of $0.9 \mathrm{ml} / \mathrm{min}$, and the injection volume was $1 \mu \mathrm{l}$. In mass spectrometry EI was performed at an electron energy of $70 \mathrm{eV}$.

Cell culture. Mouse lymphoblast P388D1 cells from the Korean Cell Line Bank (KCLB) were cultured in RPMI-1640 media with $10 \%$ fetal bovine serum (FBS).

Tumor implantation. According to the protocol of the National Cancer Institute (NCI), USA (24), 6x $10^{6}$ cells $/ 0.1 \mathrm{ml} / \mathrm{mouse}$ of mouse lymphoblast cells (P388D1) were injected into subcutaneous tissues of BDF1 mice for 21 days. The animals commenced treatment on Day 2 of control (CMC vehicle, $n=7$ ), $200 \mathrm{mg} / \mathrm{kg}$ of ar-turmerone ( $\mathrm{n}=7)$, and $10 \mathrm{mg} / \mathrm{kg}$ of Glivec (25) $(n=7)$, a positive control by daily orogastric feeding daily. For the negative control, PBS was injected into subcutaneous tissues of BDF1 mice for 21 days and CMC vehicle were treated for 20 days orally. Then, changes of tumor volume were measured with Calipus (Mitutoyo Corp., Japan) twice a week, and the tumor inhibition rate of each group was calculated according to the following formula:

inhibitory rate $(I R)$ of tumor growth $=\frac{\mathrm{C}\left(\mathrm{V}_{1}-\mathrm{V}_{0}\right)-\mathrm{T}\left(\mathrm{V}_{1}-\mathrm{V}_{0}\right)}{\mathrm{C}\left(\mathrm{V}_{1}-\mathrm{V}_{0}\right)}$ where $\mathrm{C}$ is control group, $\mathrm{T}$ is treated group (ar-turmerone or Glivec), $V_{1}$ is the volume before treatment $\left(\mathrm{mm}^{3}\right), V_{0}$ is the volume after treatment $\left(\mathrm{mm}^{3}\right)$.

This experiment was approved by the Ethics Committee for animal experiments at Dongseo University. When experimental animals are used, the NIH guidelines for laboratory animals (26) and the Korean revised law for animal protection, 8852, are followed. All precautions were taken to care for the animals and to minimize any pain or discomfort.

Tumor morphology and blood analysis. After 21 days of treatment, the mice were euthanized by cervical dislocation and thoroughly examined postmortem. Paraffin-embedded tumor samples were cut into $1 \mu \mathrm{m}$ sections and attached on glass slides. Following deparaffination and dehydration, samples were stained with hematoxylin \& eosin (H\&E). H\&E-stained ultrathin sections were observed with a light microscope (BX41TF; Olympus, Japan) with magnification, $x 1,000$. Following cervical dislocation, blood was taken immediately, and analyzed by Hemavet 950 (Drew Scientific Inc.) without pretreatment.

TUNEL assay. Paraffin-embedded tumor samples were cut into $5-\mu \mathrm{m}$ sections and attached on silane coated glass slides (Muto, Japan). Apoptosis in the tumor was measured with the In Situ Cell Death Detection kit, POD (Roche, Germany). The TUNEL assay was carried out following the manufacturer's instructions. Tissue sections were deparaffinized in xylene, and hydrated through graded ethanol and then treated with proteinase $\mathrm{K}(20 \mu \mathrm{g} / \mathrm{ml}$; Sigma, USA $)$ for $20 \mathrm{~min}$ at RT. Endogenous peroxidase was blocked by $0.3 \% \mathrm{H}_{2} \mathrm{O}_{2}$ in methanol for $15 \mathrm{~min}$ at $\mathrm{RT}$. After the reaction, tissue sections were treated with Tris- $\mathrm{HCl}$ with $3 \%$ bovine serum albumin for $30 \mathrm{~min}$ and then incubated with TUNEL reaction mixture [containing terminal deoxynucleotidyl transferase from calf thymus (enzyme solution) and nucleotide mixture (label solution)] for $1 \mathrm{~h}$ at $37^{\circ} \mathrm{C}$ in a humidified chamber. Tissue samples were then combined with converter-POD (containing antifluorescein antibody Fab fragments from sheep, conjugated with horse-radish peroxidase), followed by washing and DAB (Sigma) color reaction. During the TUNEL procedure samples were washed in PBS. Tissue sections were counterstained by hematoxylin, dehydrated through graded ethanol, cleared in xylene, and mounted. Slides were observed with a light microscope (BX41TF; Olympus) for histological analysis. As a negative control, a section was incubated with label solution only instead of using the TUNEL reaction mixture. One thousand tumor cells were counted in five different sites of each tissue section at a magnification of $\mathrm{x} 200$. The apoptotic index (AI) was calculated as follows: $\mathrm{AI}(\%)=$ (number of apoptotic cells/total number of cells) x100.

Immunohistochemical staining. Following deparaffination, the tissue sections were heated at $100^{\circ} \mathrm{C}$ for $20 \mathrm{~min}$ in $10 \mathrm{mM}$ sodium citrate buffer with $0.05 \%$ Tween-20 (pH 6.0) for antigen retrieval. Then, the sections were incubated with anti-Bax or anti-Bcl-2 antibodies (Imgenex Corp.) at a 1:200 dilution at $4^{\circ} \mathrm{C}$ overnight. After washing with PBS, the secondary antibody, Alexa Fluor ${ }^{\circledR} 488$ conjugated anti-rabbit IgG (Invitrogen), was added and cells were incubated at room temperature for $1 \mathrm{~h}$. The cells were then counterstained with $2 \mu \mathrm{g} / \mathrm{ml}$ Hoechst dye 
for visualizing the nuclei. Finally, cells were observed with fluorescence microscopy and anti-Bax or anti-Bcl-2 positive cells were detected. The number of whole cells and positive cells was counted using image analysis software (Image ${ }^{\mathrm{TM}}$ ) (NIH, Bethesda, MD, USA).

$R T-P C R$. Tumor samples were cryopreserved in liquid nitrogen and total RNA was extracted as previously described (27). Concentration of RNA was determined by the absorption at $260 \mathrm{~nm}$. The oligonucleotide primers were: Bcl-2 (716 bp), 5'-GGAAATATGGCGCACGCT-3' (sense) and 5'-TCA CTTGTGGCCCAGAT-3' (antisense); Bax (508 bp), 5'-CCA GCTCTGAGCAGATCAT-3' (sense) and 5'-TATCAGC CCATCTTCTTCC-3' (antisense); caspase-1 (1,533 bp), 5'-GAT GGCACATTTCCAGGACTGA-3' (sense) and 5'-TGTTGC AGATAATGAGGGCAAGAC-3' (antisense); caspase-3 (1,466 bp), 5'-CTGCCGGAGTCTGACTGGAA-3' (sense) and 5'-ATCAGTCCCACTGTCTGTCTCAATG-3' (antisense); caspase-6 (1,281 bp), 5'-ACGTTGACTGGCTTGTTCAA AGG-3' (sense) and 5'-GCGTGTACACAGACGCAGCA-3' (antisense); caspase-9 (3,896 bp), 5'-GCTGGAACACTGG GCATTGA-3' (sense) and 5'-GGCCTGATACCCAAGCAG GA-3' (antisense); glyceraldehyde-3-phosphate dehydrogenase (GAPDH), 5'-CGGAGTCAACGGATTTGGTCGTAT-3' (sense) and 5'-AGCCTTCTCCATGGTGGTGAAGAC-3' (antisense). Polymerase chain reactions were performed in a $50 \mu \mathrm{l}$ reaction volume. PCR products were electrophoresed on agarose gel, and photographed under UV light, after staining with ethidium bromide.

Lymphocyte proliferation assay. The effects of ar-turmerone on ex vivo lymphoproliferative responses in splenocyte cultures isolated from chronically ar-turmerone-exposed and untreated tumor-implanted BDF1 mice were determined, respectively. Spleen cell suspensions from the mice were prepared in Earle's balanced salt solution (EBSS), washed and resuspended in RPMI-1640 medium containing 5\% FBS, 2 mM L-glutamine, $100 \mathrm{U} / \mathrm{ml}$ penicillin, $100 \mu / \mathrm{ml}$ streptomycin and $50 \mu \mathrm{Mmercapto}-$ ethanol (ME). The cell number was adjusted to $1.25 \times 10^{6} \mathrm{cell} / \mathrm{s} / \mathrm{ml}$ of culture media. Cells were distributed in 96-well plates (Costar, Cambridge, MA, USA) in $180 \mu 1$ volume. The cultures were incubated in a humidified $5 \% \mathrm{CO}_{2}$ incubator at $37^{\circ} \mathrm{C}$ for $72 \mathrm{~h}$ with a given concentration of mitogen in $20 \mu \mathrm{l}$, either lipopolysaccharide (LPS) $(50 \mu \mathrm{g} / \mathrm{ml})$ or concanavalin A (Con A; $1 \mu \mathrm{g} / \mathrm{ml}$ ). Following incubation, $20 \mu \mathrm{l}$ of Cell Titer 96 aqueous nonradioactive cell proliferation kit (Promega) was added in each well, and then the plate was incubated for an additional $4 \mathrm{~h}$. The plate was read on an ELISA reader (Bio-Rad) using a wavelength of $490 \mathrm{nM}$. Results were expressed as mean absorbance minus the negative control's absorbance.

Assay of intracellular interleukin-2 (IL-2) production. Prepared cell suspensions from drug-exposed and untreated BDF1 mice were homogenated in RPMI-1640 medium containing 5\% FBS, $2 \mathrm{mM} \mathrm{L}$-glutamine, $100 \mathrm{U} / \mathrm{ml}$ penicillin, $100 \mu \mathrm{g} / \mathrm{ml}$ streptomycin and $50 \mu \mathrm{M}$ ME. The spleen cells were adjusted to $1 \times 10^{6}$ cells $/ \mathrm{ml}$ and $180 \mu 1$ of cells were distributed in 24-well plates with $20 \mu \mathrm{l}$ of Con A $(2 \mu \mathrm{g} / \mu \mathrm{l})$ and recombinant IL-2 (rIL-2; Roche). Following incubation at $37^{\circ} \mathrm{C}$ for $24 \mathrm{~h}$, brefeldin $\mathrm{A}\left(10 \mu \mathrm{g} / 10^{6}\right.$ cells $)$ was added and postincubated for another $5 \mathrm{~h}$. Then, the cells were washed with staining buffer and blocked nonspecific binding by adding anti-mouse CD16/CD32 $\mathrm{Fc}$ receptor $\left(1 \mu \mathrm{g} / 10^{6}\right.$ cell/ tube) for $20 \mathrm{~min}$ on ice. The CD4 cells were identified using FITC-conjugated anti-mouse CD4 (0.5 $\mu \mathrm{g} /$ tube; clone, GK 1.5) $\mathrm{mAb}$, which was suspended in staining buffer and incubated for $30 \mathrm{~min}$ on ice in a dark room. To fix and permeabilize the cells, Cytofix/Cytoperm solution (100 $\mu 1 /$ tube) was added and postincubated on ice for $20 \mathrm{~min}$ in the dark. Then 1X Perm/ Wash solution (1 ml/tube) was added for washing and centrifuged two times at $4^{\circ} \mathrm{C} 1,500 \mathrm{rpm}$. Subsequently, $100 \mu \mathrm{l}$ of Perm/Wash solution with anticytokine mAbs (PE-conjugated anti-mouse IL-2) were added and the cells were postincubated for $30 \mathrm{~min}$ on ice in the dark. Finally, 1X Perm/Wash solution ( $1 \mathrm{ml} /$ tube) was added for washing and centrifugation two times at $4^{\circ} \mathrm{C} 1,500 \mathrm{rpm}$, and analyzed with flow cytometry after mixing with staining buffer (300 $\mu 1 /$ tube).

Data analysis. Data were analyzed by one-way ANOVA, Student's t-test or Tukey's HSD test.

\section{Results}

The effect of ar-turmerone on tumor incidence and hemocytes. First, we treated $200-400 \mathrm{mg} / \mathrm{kg}$ of ar-turmerone on normal BDF1 mice. The highest dose of ar-turmerone $(400 \mathrm{mg} / \mathrm{kg} /$ day $)$ caused severe diarrhea in the afternoon and decreased body weight, so the treatment could not be prolonged to 10 days. Then, we used reduced doses ( 200 or $300 \mathrm{mg} / \mathrm{kg} / \mathrm{day}$ ) of ar-turmerone on BDF1 mice transplanted with P388D1 lymphoblast cells. A few of the mice treated with a higher dose of ar-turmerone $(300 \mathrm{mg} / \mathrm{kg}$ ) showed diarrhea in the afternoon, and significantly reduced body weight (data not shown), therefore, according to the NCI manual, we could not continue ar-turmerone treatment and lymphoblast cell injections.

Lymphoma was induced by 21 days of P388D1 administration following the NCI manual (24). Tumor inhibition rates of ar-turmerone and Glivec were 11.79 and $14.16 \%$ (Table I). One of each of the experimental groups is shown in Fig. 1, and necrotic morphology is hardly shown compared to the negative control PBS group (Fig. 1). Control group, or P388D1 + CMC group, showed increased number of white blood cells (WBCs) compared to the negative control group, or PBS group $(\mathrm{P}<0.001)$. The number of WBCs in the ar-turmerone-treated group and the Glivec-treated group dropped significantly compared to the control group, P388D1 + CMC ( $\mathrm{P}<0.001)$.

Although the WBC number and neutrophile percentage of the ar-turmerone- or Glivec-treated group decreased compared to the control P388D1 + CMC group at $\mathrm{P}<0.001$, the lymphocyte percentage increased compared to control at $\mathrm{P}<0.001$ (Table II). The number of red blood cells (RBCs) of the ar-turmerone- and the Glivec-treated group was not different from that of the control group in tumor-implanted mice. The number of hemoglobins in the ar-turmerone-treated group increased compared to control (Table II).

Apoptotic tumor cells by ar-turmerone. Positive staining was clearly shown in nuclei (Fig. 2). The apoptosis index (AI) of the control group, the ar-turmerone group and the Glivec group were $4.22 \pm 1.02,5.45 \pm 1.46$ and $10.01 \pm 2.01$, respectively. 
Table I. Effect of ar-turmerone on tumor incidence and WBCs in BDF1 mice.

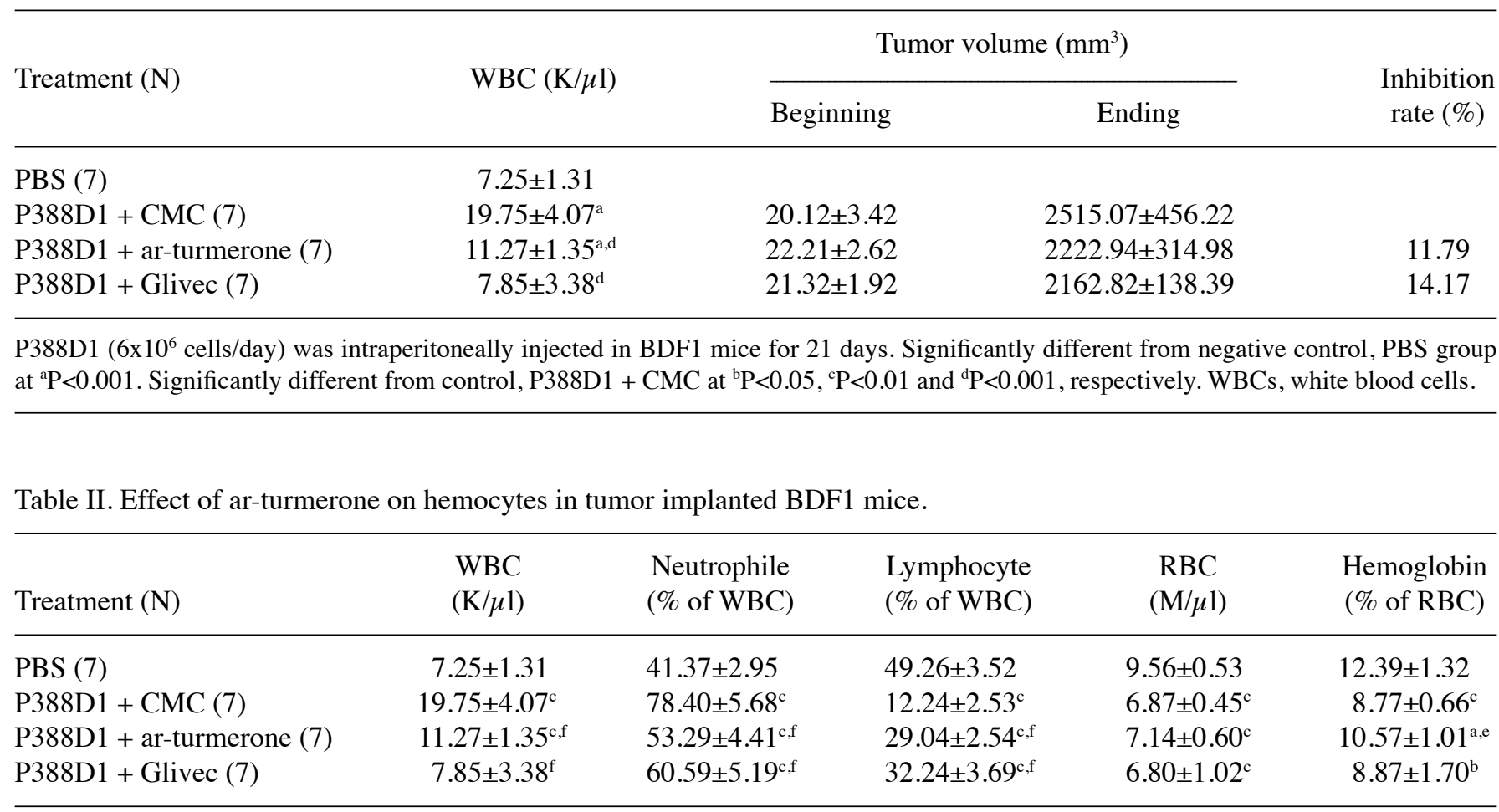

P388D1 (6x10 cells/day) was intraperitoneally injected in BDF1 mice for 21 days. Significantly different from negative control, PBS group at ${ }^{\mathrm{P}} \mathrm{P}<0.05,{ }^{\mathrm{b}} \mathrm{P}<0.01$ and ${ }^{\mathrm{c}} \mathrm{P}<0.001$, respectively. Significantly different from control, $\mathrm{P} 388 \mathrm{D} 1+\mathrm{CMC}$ at ${ }^{\mathrm{d}} \mathrm{P}<0.05,{ }^{\mathrm{e}} \mathrm{P}<0.01$ and ${ }^{\mathrm{f}} \mathrm{P}<0.001$, respectively. WBC, white blood cell. RBC, red blood cell.
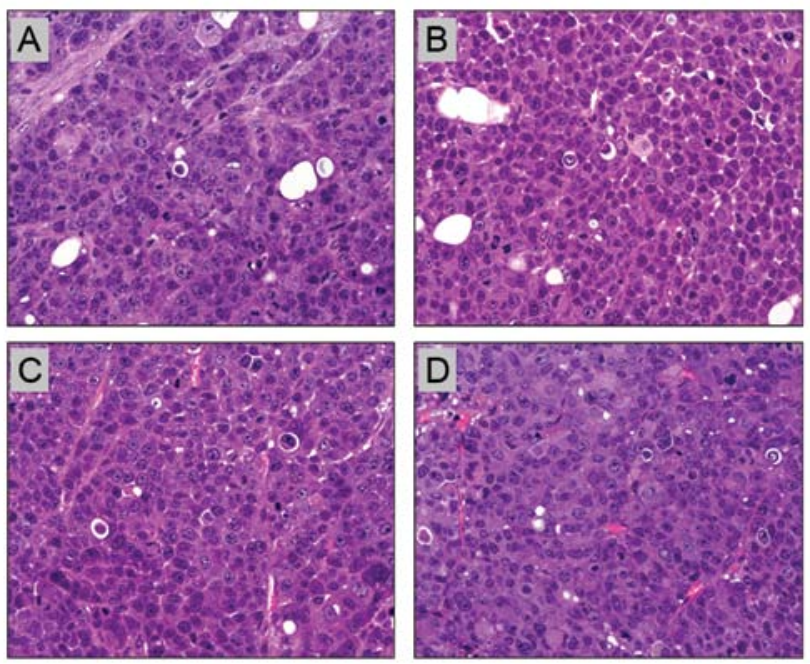

Figure 1. Microscopic structures of transplanted tumor cells induced by drugs (original magnification, $x 1,000$ ) of H\&E staining. (A) PBS, (B) P388D1 + CMC, (C) P388D1 + ar-turmerone and (D) P388D1 + Glivec. Animal IDs of A, B, C, $\mathrm{D}$ is $5,10,20,26$, respectively.

AI value of the ar-turmerone-treated group increased slightly, but it did not show a significance. Only the Glivec-treated group showed a significant difference at $\mathrm{P}<0.05$ compared to the control group (Table III).

Expression of Bcl-2 and Bax proteins. Bcl family protein level was measured only in implanted tumor cells. Positive
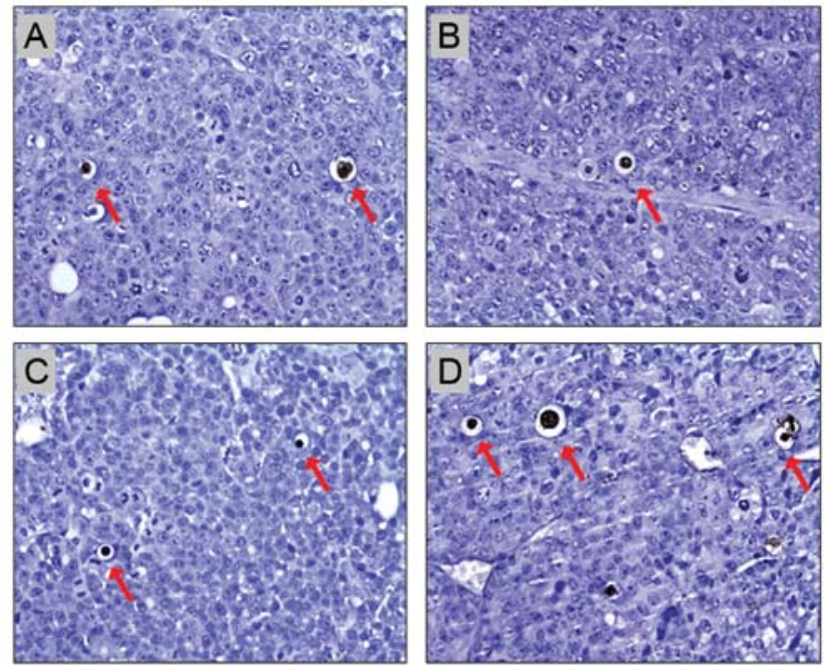

Figure 2. Apoptotic tumor cells/mouse lymphoblast cells, P388D1, xenograft (original magnification, $\mathrm{x} 400$ ). TUNEL positive cells are observed in the tumor mass (arrows). (A) PBS, (B) P388D1 + CMC, (C) P388D1 + ar-turmerone and (D) P388D1 + Glivec. Animal IDs of A, B, C, D is 5, 10, 20, 26, respectively.

staining was located in the cytoplasm. The positive rates of Bcl-2 protein expression in the control, ar-turmerone and Glivec groups were $13.20 \pm 1.32,11.92 \pm 1.04$ and $12.36 \pm 2.02 \%$, respectively. The positive rates of Bax protein expression in the control, ar-turmerone and Glivec groups were $14.12 \pm 1.82$, $18.34 \pm 3.62$ and $22.33 \pm 2.82 \%$, respectively, in which the Glivec-treated group showed a marked change at the $1 \%$ level (Table IV). 
Table III. Apoptotic index (AI) of implanted tumors in BDF1 mice (mean \pm SD).

\begin{tabular}{ccccc}
\hline & PBS & P388D1 + CMC & P388D1 + ar-turmerone & P388D1 + Glivec \\
\hline $\mathrm{AI}(\%)$ & $0.85 \pm 0.16$ & $4.22 \pm 1.02$ & $5.45 \pm 1.46$ & $10.01 \pm 2.01^{\mathrm{a}}$ \\
\hline
\end{tabular}

${ }^{\text {a }} \mathrm{P}<0.05$ vs. the control group, $\mathrm{P} 388 \mathrm{D} 1+\mathrm{CMC}$, by the Student's t-test.

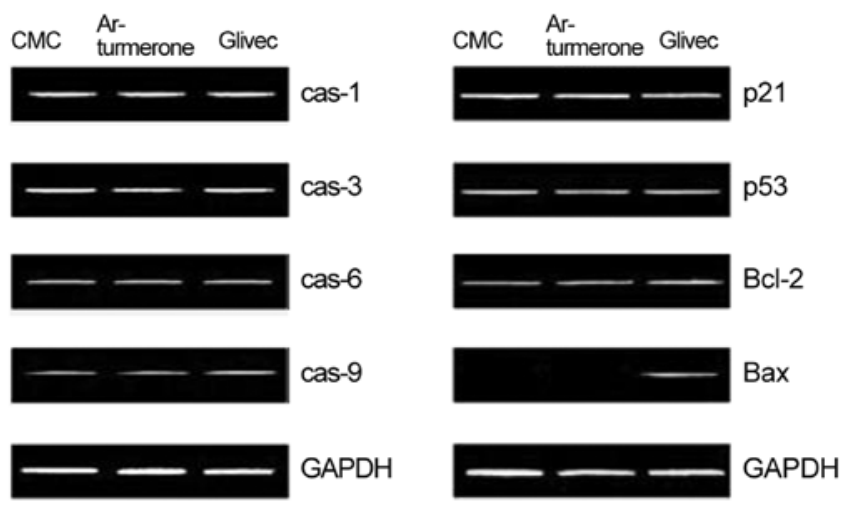

Figure 3. Effect of ar-turmerone on the level of Bcl-2, Bax, P53, P21 and caspase-1, -3, -6, -9 mRNA expression on implanted tumor cells by P388D1. Total RNA was isolated and RT-PCR was performed using indicated primers.

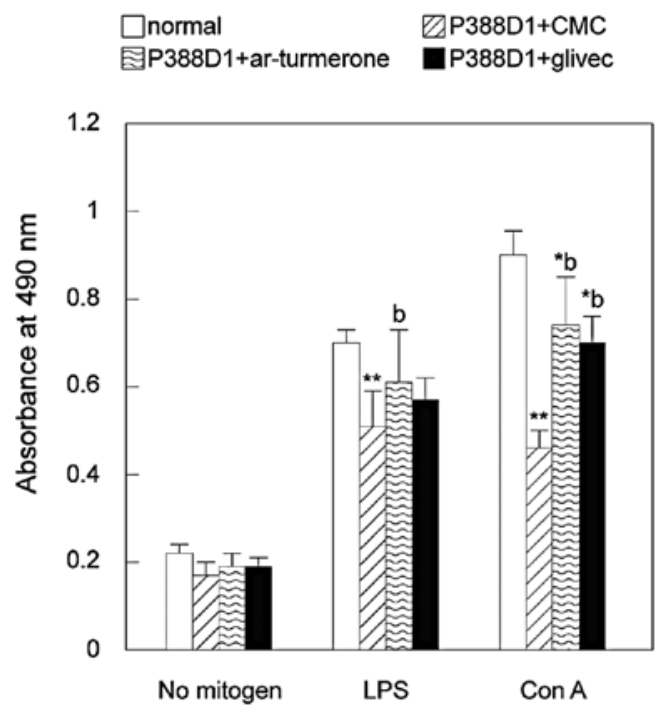

Figure 4. Effect of ar-turmerone on ex vivo lymphoproliferative responses in splenocyte cultures from male BDF1 mice bearing P388D1 cells. Splenocytes isolated from each drug-treated mouse were cultured for $72 \mathrm{~h}$ in the presence of either bacterial lipopolysaccharide (LPS) or concanavalin A (Con A). Each bar represents the mean absorbance at $490 \mathrm{~nm} /$ well \pm SE of 7 animals. The asterisks indicate the values significantly different from the normal BDF mice at ${ }^{*} \mathrm{P}<0.05,{ }^{* *} \mathrm{P}<0.01$. The (b) indicates the values significantly different from the positive control (P388D1 + CMC) at $\mathrm{P}<0.01$.

Expression of caspases and Bcl family $m R N A$. The main signaling gene expression level was measured only in implanted tumor cells. The density of caspase-1, -3, -6, -9, Bcl-2, Bax, p21 and p53 mRNA in the control, ar-turmerone and Glivec groups is shown in Fig. 3. Most signals in both the ar-turmerone- and Glivec-treated groups did not show differences, with the excep-
Table IV. Positive rate of Bcl-2 and Bax proteins of implanted tumors in BDF1 mice.

\begin{tabular}{lcc}
\hline & $\begin{array}{c}\text { Bcl-2 }(\%) \\
\text { mean } \pm \text { SE }\end{array}$ & $\begin{array}{c}\text { Bax }(\%) \\
\text { mean } \pm \text { SE }\end{array}$ \\
\hline P388D1 + CMC & $13.20 \pm 1.32$ & $14.12 \pm 1.82$ \\
P388D1 + ar-turmerone & $11.92 \pm 1.04$ & $18.34 \pm 3.62$ \\
P388D1 + Glivec & $12.36 \pm 2.02$ & $22.33 \pm 2.82^{\text {a }}$ \\
\hline
\end{tabular}

${ }^{\text {a }} \mathrm{P}<0.01$ vs. the control group, $\mathrm{P} 388 \mathrm{D} 1+\mathrm{CMC}$, by Tukey's HSD test.

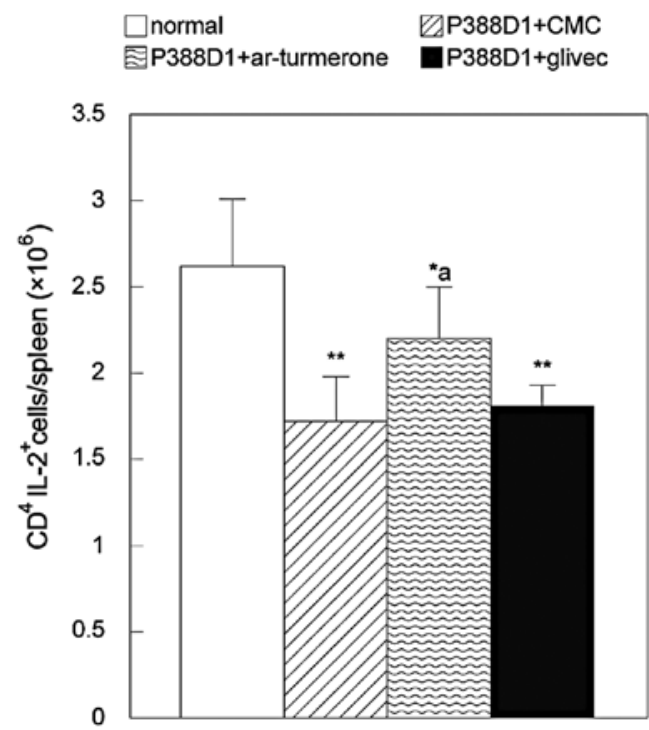

Figure 5. Effect of ar-turmerone on splenic intracellular IL-2 production in male BDF1 mice bearing P388D1 cells. Splenocytes isolated from each drug-treated mouse were cultured for $12 \mathrm{~h}$ in the presence of concanavalin A. Each bar represents the mean \pm SE of 7 animals. The asterisks indicate the values significantly different from the normal $\mathrm{BDF}$ mice at ${ }^{*} \mathrm{P}<0.05,{ }^{* *} \mathrm{P}<0.01$. The (a) indicates the values significantly different from the positive control $(\mathrm{P} 388 \mathrm{D} 1+\mathrm{CMC})$ at $\mathrm{P}<0.05$.

tion of the Bax mRNA of the Glivec-treated group, which increased compared to the control group (Fig. 3).

Effect of ar-turmerone on lymphocyte proliferation. The lymphocyte proliferation activities of tumor cells decreased compared to the negative control PBS group. T-lymphocytes proliferated with the induction of Con A, and B-lymphocytes proliferated with the induction of LPS (Fig. 4). In LPS induced treatment, B-lymphocyte proliferation of the control, ar-turmerone- and Glivec-treated groups decreased compared to the negative control (normal), but the control 
group $(\mathrm{P} 388 \mathrm{D} 1+\mathrm{CMC})$ only showed significance at $\mathrm{P}<0.01$. B-lymphocyte proliferation of the ar-turmerone- and the Glivec-treated group increased compared to the control group. In Con A-induced treatment, T-lymphocyte proliferation of control significantly decreased compared to the negative control $(\mathrm{P}<0.01)$, and the T-lymphocyte proliferation of the ar-turmerone- and the Glivec-treated group also decreased $(\mathrm{P}<0.05)$. T-lymphocyte proliferation of the ar-turmerone- and the Glivec-treated group significantly increased compared to the control group (P388D1 + CMC) $(\mathrm{P}<0.01)$.

Effect of ar-turmerone on IL-2 production. The change in cytokine production activity caused by drugs is very important, especially in IL-2 production activity that affects T-cell differentiation $(28,29)$. IL-2 production activity of P388D1 in implanted tumor cells decreased significantly compared to the negative control group. IL-2 production in the ar-turmeronetreated group increased compared to the control group $(\mathrm{P}<0.05)$, but IL-2 production in the Glivec-treated group did not increase in implanted tumor cells (Fig. 5).

\section{Discussion}

Discovering new antitumor drugs with less toxicity is an ongoing challenge in cancer research. Our previous study showed that ar-turmerone was able to induce apoptosis in human lymphoma, or U937 cells (8). The apoptosis accompanied downregulation of the antiapoptotic gene, Bcl-2, and upregulation of the pro-apoptotic gene, Bax, at the same time. This present study further investigated the effect of ar-turmerone on implanted tumors of mouse lymphoblast cells, P388D1, and its molecular mechanisms, to provide an additional theoretical basis for a chemotherapeutic application of ar-turmerone.

Ar-turmerone showed a slight ability to inhibit tumor growth similarly to the Glivec-treated, positive control group. However, it showed a great ability to decrease the number of WBCs, which increased with the injection of P388D1 (Table I). This result suggests that ar-turmerone does not have a therapeutic effect on tumor incidence, but it has a repressive effect on P388D1 lymphocytic leukemia. Although the WBC number and neutrophile percentage of the ar-turmerone- or the Glivec-treated group decreased compared to the control, P388D1 + CMC, group, the lymphocyte percentage increased compared to control (Table II). Based on these findings, ar-turmerone is considered to be associated with the immune system.

Although the chemotherapeutic effect of ar-turmerone was not evident, we cannot ignore its possible ability to induce apoptosis. Apoptosis is a systematically regulated process that involves the expression of several gene products. The prosurvival Bcl-2 subfamily and pro-apoptotic Bax subfamily can oppositely regulate apoptosis through the control of cytochrome release from the mitochondria, resulting in caspase activation (17,30-32). For example, caspase-3 cleaves Bcl-2 and $\mathrm{Bcl}-\mathrm{xL}$, thus destroying the antiapoptotic function of these proteins, and releases C-terminal fragment that is proapoptotic. This study found that the ar-turmerone group did not increase AI value and protein and mRNA levels of Bax, Bcl-2 and caspases (Fig. 3). From these results, it is considered that ar-turmerone does not affect protein and mRNA levels which lead to apoptosis in implanted tumor cells.

Recent studies have demonstrated that tumor cell responses are regulated by immune reactions such as lymphocyte homing and activation (33-35). In this study, we investigated the interactions between implanted tumor cells and lymphocytes, and examined potential immunotherapeutic approaches targeting lymphoblast implantation-cytokine production activity. Based on the results that B- and T-lymphocyte proliferation activity in the ar-turmerone group increased significantly compared to the control group (Fig. 4), it is suggested that ar-turmerone can prevent the decrease of lymphocyte proliferation activity in implanted tumor mice. Therefore, increased lymphocyte proliferation activity by ar-turmerone is assumed to increase the lymphocyte percentage to WBCs compared to control (Table II). Considering this increased proliferation activity of ar-turmerone was more significantly shown in T-lymphocytes than in B-lymphocytes, we investigated the production of T-lymphokines, which is IL-2, that is required for immune cell maturation and activation $(36,37)$. From the result that IL-2 production in the ar-turmerone-treated group increased compared to the control group, it is suggested that ar-turmerone possesses an immune activating activity.

Collectively, these findings suggest that ar-turmerone does not have a chemotherapeutic effect on tumor incidence, but it has a repressive effect on P388D1 lymphocytic leukemia. It is also suggested that this protective effect of ar-turmerone from P388D1 lymphocytic leukemia resulted from the increased activity of tumor immunogenicity through increased T-lymphokine production and increased percentage of lymphocytes.

\section{Acknowledgements}

This study was supported by the National Research Foundation of Korea (NRF: 2009-0071651).

\section{References}

1. Roth GN, Chandra A and Nair MG: Novel bioactivities of Curcuma longa constituents. J Nat Prod 61: 542-545, 1998.

2. Manzan AC, Toniolo FS, Bredow E and Povh NP: Extraction of essential oil and pigments from Curcuma longa [L] by steam distillation and extraction with volatile solvents. J Agric Food Chem 51: 6802-6807, 2003.

3. Lee HS, Shin WK, Song C, Cho KY and Ahn YJ: Insecticidal activities of ar-turmerone identified in curcuma longa rhizome against Nilapatvata lugens (Homoptera: Delphacidae) and Plutella xylostella (Lepidopteta: Yponomeutidae). J Asia Pac Entomol 4: 181-185, 2001.

4. Ferreira LA, Henriques OB, Andreoni AA, Vital GR, Campos MM, Habermehl GG and Moraes VL: Antivenom and biological effects of ar-turmerone isolated from Curcuma longa (Zingiberaceae). Toxicon 30: 1211-1218, 1992.

5. Lee JH, Kang SK and Ahn BZ: Antineoplastic natural products and the analogues XI cytotoxic activity against L1210 cell of some raw drugs from the oriental medicine and folklore. Korean J Pharmacog 17: 286-291, 1986.

6. Baik KU, Jung SH and Ahn BZ: Recognition of pharmacophore of ar-turmerone for its anticancer activity. Arch Pharm Res 16: 254-256, 1993.

7. Aratanechemuge Y, Komiya T, Moteki H, Katsuzaki H, Imai K and Hibasami H: Selective induction of apoptosis by ar-turmerone isolated from turmeric (Curcuma longa $\mathrm{L}$ ) in two human leukemia cell lines, but not in human stomach cancer cell line. Int J Mol Med 9: 481-484, 2002.

8. Lee YK: Activation of apoptotic protein in U937 cells by a component of turmeric oil. BMB Rep 42: 96-100, 2009. 
9. Wyllie AH, Kerr JF and Currie AR: Cell death: the significance of apoptosis. Int Rev Cytol 68: 251-306, 1980.

10. Liu X, Kim CN, Yang J, Jemmerson R and Wang X: Induction of apoptotic program in cell-free extract: requirement for dATP and cytochrome c. Cell 80: 147-157, 1996.

11. Li P, Nijhawan D, Budihardjo I, Srinivasula SM, Ahmad M, Alnemri ES and Wang X: Cytochrome c and dATP-dependent formation of Apaf-1/caspase complex initiates an apoptotic protease cascade. Cell 91: 479-489, 1997.

12. Stennicke HR and Salvesen GS: Properties of the caspases. Biochim Biophys Acta 1387: 17-31, 1998.

13. Miyashita T, Krajewski S, Krajewska M, Wang HG, Lin HK, Liebermann DA, Hoffman B and Reed JC: Tumor suppressor p53 is a regulator of Bcl-2 and Bax gene expression in vitro and in vivo. Oncogene 9: 1799-1805, 1994.

14. Lowe SW, Ruley HE, Jacks T and Housman DE: p53-dependent apoptosis modulates the cytotoxicity of anticancer agents. Cell 74: 957-967, 1993.

15. El-Deiry WS, Tokino T, Velculescu VE, Levy DB, Parsons R, Trent JM, Lin D, Mercer WE, Kinzler KW and Vogelstein B WAF1, a potential mediator of p53 tumor suppression. Cell 75 : 817-825, 1993.

16. Tsujimoto Y: Role of Bcl-2 family proteins in apoptosis: apoptosomes or mitochondria? Genes Cells 3: 697-707, 1998.

17. Rosse T, Olivier R, Monney L, Rager M, Conus S, Fellay I, Jansen B and Borner C: Bcl-2 prolongs cell survival after Bax-induced release of cytochrome c. Nature 391: 496-499, 1998

18. Finucanne DM, Bossy-Wetzel E, Waterhouse NJ, Cotter TG and Green DR: Bax-induced caspase activation and apoptosis via cytochrome c release from mitochondria is inhibitable by Bcl-xL. J Biol Chem 274: 2225-2233, 1999.

19. Hirschhorn-Cymerman D, Rizzuto GA, Merghoub T, Cohen AD, Avogadri F, Lesokhin AM, Weinberg AD, Wolchok JD and Houghton AN: OX40 engagement and chemotherapy combination provides potent antitumor immunity with concomitant regulatory T cell apoptosis. J Exp Med 206: 1103-1116, 2009.

20. Ko HJ, Kim YJ, Kim YS, Chang WS, Ko SY, Chang SY, Sakaguchi $S$ and Kang CY: CYA combination of chemoimmunotheraphies can efficiently break self-tolerance and induce antitumor immunity in a tolerogenic murine tumor model. Cancer Res 67: 7477-7486, 2007.

21. Bunt SK, Yang L, Sinha P, Clements VK, Leips J and Ostrand-Rosenberg S: Reduced inflammation in the tumor microenvironment delays the accumulation of myeloid-derived suppressor cells and limits tumor progression. Cancer Res 67: 10019-10026, 2007

22. Suzuki E, Kapoor V, Jassar AS, Kaiser LR and Albelda SM: Gemcitabine selectively eliminates splenic $\mathrm{Gr}-1^{+} / \mathrm{CD} 11 \mathrm{~b}^{+}$myeloid suppressor cells in tumor-bearing animals and enhances antitumor immune activity. Clin Cancer Res 11: 6713-6721, 2005.

23. Hong $\mathrm{CH}$, Kim YL and Lee SK: Sesquiterpenoids from the Rhizome of Curcuma zedoaria. Arch Pharm Res 24: 424-426, 2001.
24. Goldin A, Sofina Z and Cyrkin A: Experimental evaluation of antitumor drugs in the USA and USSR and clinical correlations. Natl Cancer Inst Monogr 55: 25-26, 1980.

25. Herman EH, Knapton A, Rosen E, Thompson K, Rosenzweig B, Estis J, Agee S, Lu QA, Todd JA, Lipshultz S, Hasinoff B and Zhang J: A multifaceted evaluation of imatinib-induced cardiotoxicity in rat. Toxicol Pathol 39: 1091-1106, 2011.

26. Guide for the Care and Use of Laboratory Animals. Institute of Laboratory Animal Resources Commission on Life Sciences, National Research Council. National Academy Press, Washington, DC, 1996.

27. Lee YK: Induction of apoptosis by S-allylmercapto-L-cysteine, a biotransformed garlic derivative, on a human gastric cancer cell line. Int J Mol Med 21: 765-770, 2008.

28. Pallardy MJ, House RV and Dean JH: Molecular mechanism of 7,12-dimethylbenz [a] anthracene-induced immunosuppression: evidence for action via the interleukin-2 pathway. Mol Pharmacol 36: 128-133, 1989.

29. Smith KA: Interleukin-2: inception, impact, and implications. Science 240: 1169-1976, 1988.

30. Thornberry NA, Bull HG, Calaycay JR, Chapman KT, Howard AD, Kostura MJ, Miller DK, Molineaux SM, Weidner JR, Aunius $\mathrm{J}$, et al: A novel hetero-dimeric cysteine protease is required for interleukin-1 beta processing in monocytes. Nature 356: 768-774, 1992.

31. Yuan J, Shaham S, Ledoux S, Ellis HM and Horvitz HR: The C. elegans cell death gene ced-3 encodes a protein similar to mammalian interleukin-1 beta-converting enzyme. Cell 75: 641-652, 1993.

32. Sentman CL, Shutter JR, Hockenbery D, Kanagawa O and Korsmeyer SJ: Bcl-2 inhibits multiple forms of apoptosis but not negative selection in thymocytes. Cell 67: 879-888, 1991.

33. Gorgun $\mathrm{G}$ and Anderson KC: Intrinsic modulation of lymphocyte function by stromal cell network: advance in therapeutic targeting of cancer. Immunotherapy 3: 1253-1264, 2011.

34. Chanan-Khan AA, Chitta K, Ersing N, Paulus A, Masood A, Sher T, Swaika A, Wallce PK, Mashtare TL Jr, Wilding G, Lee K, Czuczman MS, Borrello I and Bangia N: Biological effects and clinical significance of lenalidomide-induced tumour flare reaction in patients with chronic lymphocytic leukaemia: in vivo evidence of immune activation and antitumour response. $\mathrm{Br} \mathrm{J}$ Haematol 155: 457-467, 2011.

35. Curigliano G: Immunity and autoimmunity: revising the concepts of response to breast cancer. Breast 20 (Suppl 3): S71-S74, 2011.

36. Myers MJ, Blanton RH and Bick PH: Inhibition of IL-2 responsiveness following exposure to benzo(a)pyrene is due to alterations in accessory cell function. Int J Immunopharmacol 10: $177-186,1988$

37. Lyte M, Blanton RH, Myers MJ and Bick PH: Effect of in vivo administration of the carcinogen benzo(a)pyrene on interleukin-2 and interleukin-3 production. Int J Immunopharmacol 9: 307-312, 1987 